\title{
Institutionalisation and Resistance: Organic Agriculture in Australia and New Zealand
}

\author{
Kristen Lyons \\ Lecturer in Sociology \\ Central Queensland University \\ Rockampton QId AUSTRALIA \\ Email: k.lyons@cqu.edu.au \\ Geoffrey Lawrence \\ Foundation Professor of Sociology \\ Director, Institute for Sustainable Regional Development \\ Central Queensland University \\ Rockhampton QId AUSTRALIA \\ Email: g.lawrence@cqu.edu.au
}

\section{Introduction}

The expansion of the organics industry in Australia and New Zealand is premised upon the continued institutionalisation of what was once considered to be a marginal 'unscientific' approach to farming. What is emerging is the integration of organic practices within conventional food systems - something that many commentators would not have predicted, but which appears to fit well with theories of 'greening'. With growth in the number and influence of organic certification (and other regulatory) bodies, and the evolution of profitable international markets, commercial growers as well as transnational companies have entered the industry. As a consequence of seemingly entrenched philosophical and other differences there has been a growing rift in Australia and New Zealand between the 'new' commercially-focused organic producers, and the more orthodox organic producers whose practices continue to be based upon a rejection of scientific agriculture. Many within the latter group have devised sites of resistance which form the basis for ongoing contestation between their own attitudes and practices, and those of the 'new' growers.

This paper reports findings from the first large-scale comparative study of the organics industry in Australia and New Zealand. It examines the ways organics is becoming increasingly institutionalised, and explores the motivations of producers in 'going organic'. It concludes by suggesting that the future shape of the industry is likely to remain bifurcated as the two main groups struggle to assert their own definitions of organic.

'Greening' and the Place of Organics 
The developing interest by sociologists in organic farming parallels what has been termed the 'greening' of agriculture and the food industry. 'Greening' describes the process of change in the ideologies and practices of (largely) western social systems as they move toward the incorporation of ecological discourses, and of practices which seek to address environmental concerns (see Burch et al. 1999). For writers such as Thomashow (1995: 139) a growing environmental consciousness is linked firmly to the development of the 'ecological citizen' as someone who

takes responsibility for the place where he or she lives, understands the importance of making collective decisions regarding the commons, seeks to contribute to the common good, identifies with bioregions and ecosystems rather than obsolete nation-states or transnational corporations, considers the wider impact of his or her actions, is committed to mutual and collaborative community building...and acts according to his or her convictions (Thomashow, 1995: 139).

For Eder (1996) the western world is viewed as having entered the era of modern environmentalism in the late 1960s. Since that time a three-phase development has unfolded. The first phase was characterised by the simple realisation that environmental problems arose from the incompatibility between existing production regimes and ecological systems. The second phase was that of regulation; in order to protect the environment the state must act to prevent certain practices and outcomes from occurring (regulating for sustainable production is seen to fit here). The third phase - that emerging in the late 1990s - has been one based on knowledge, and acceptance of the underlying principles of eco-systemic processes and typified by the 'cultural normalisation' of environmental concerns and their acceptance within established patterns of thinking (see Eder, 1996: 163).

Organic production has been an important, albeit small, part of these changes. Because of the hegemonic position of productivist agriculture, organics has struggled to be recognised as a legitimate and alternative approach to food and fibre production in agricultural economies dominated by productivity and efficiency concerns. While 'sustainability' has had increased saliency in agri-food discourse and its practical manifestations have included new environmentally-friendly production options such as minimum tillage, it has tended to endorse the modification of current, 'high tech' strategies, rather than contributing to their abandonment and replacement. It has allowed producers feel they are farming sustainably by embracing industry best practices, while leaving the basic elements of a polluting and ecologically-damaging agriculture in place (Lawrence, 1996; Lawrence, 1999; Lockie, 1999). Who needs to consider 'going organic' when one can farm in a sustainable way by tinkering at the edges of conventional production?

Organics has also faced the wrath of those who want to ensure it retains its marginalised position, so that there is no doubt in the minds of governments or consumers about the need for continuation with high production chemical farming. Avery (1995) in his provocatively titled, but ideologically crass, Saving the Planet with Pesticides and Plastic argues that organics, inter alia, produces lower and erratic yields, is incapable of sustaining soil fertility, increases soil erosion (through tillage), cannot result in any 'natural' balance between production and pests, and has no ability whatsoever of 
providing a foundation for feeding the world's burgeoning population. Along with the views that organic production is a quaint, self-sufficient, option for 'greenies', and that export-producing nations could never expect the volumes of production from organics that were achieved with high tech agriculture, Avery's sentiments are basically those that have underpinned scientific agriculture in Australia and New Zealand (see Malcolm et al., 1996). More pointedly, such views have been in accordance with what Youngberg et al., (1993: 298) have summarised as the US government position - that organic agriculture was a 'primitive, backward, nonproductive, unscientific technology suitable only for the nostalgic and disaffected back-to-the-landers of the 1970s'. Until recent times, these sentiments have largely prevented serious consideration of an 'organic future' for rural production in countries such as the US, Australia and New Zealand.

However, as Thomashow (1995) and Eder (1996) have suggested, the growth of a 'green' environmental consciousness - present in Australia and New Zealand as much as anywhere else in the world - has encouraged the development of what are perceived to be less polluting forms of farming. In this sense, western 'greening' has allowed organics to emerge from its previously marginalised position. Two related factors - health/'food security' issues and the rise of 'green protectionism' (see Campbell and Coombes 1999a; Lawrence et al. forthcoming) are viewed as important elements in the move to organics. Premium prices for organic foods in countries like Japan (where the market is estimated to be some A $\$ 40$ billion) has demonstrated to Australian and New Zealand producers, and particularly New Zealand transnationals, that the export of organics is an important 'keyhole' market channel (see Monk, 1999; Penfold and Miyan, 1999). Within this context, the Australian and New Zealand organic industries have undergone recent and rapid growth. Estimates indicate the Australian organic industry has increased in value from A \$28 million in 1990 toA \$200 million by 1999, while in New Zealand the industry has grown from NZ\$1.1 million in 1988 to NZ\$33.5 million by 1996 (Kinnear, 1999; RIRDC, 1996; Saunders et al, 1997).

As we will discuss below, the move toward what might be termed the 'institutionalisation' of organics - referring to the integration of organics within conventional food systems highlights both a positive response to the export opportunities for organics, and a growing tension between the principles and practices of what we have termed 'orthodox' organic growers and those of the more recent entrants to organic farming. Processes of institutionalisation are evidenced in the entry of corporate actors, scientific advisory services as well as government regulatory organisations to the organic industry. Importantly, these processes are evidenced more prominently in New Zealand than Australia. Within this context of formalisation, there appears to be somewhat of a bifurcation amongst growers engaged in the industry. Without wishing to oversimplify the diversity of values and beliefs amongst those engaged in the organic movement, there appears to be some challenge and contestation between those orthodox farmers attracted by the possibilities of organics to develop a more sustainable agriculture, and the newcomers, who have been significantly swayed by profit-making opportunities that have driven the current (and unsustainable) system of agricultural production. Examining the historical formation of the organic industry highlights the significance of the symbolic meanings associated with food and food production in initiating this movement, and provides the background to contextualise current contestation amongst growers as an 
outcome of recent transformation of the industry, marking a substantial shift from its historical roots.

\section{Institutionalising Organics}

The organic agriculture/food movement that began to expand early this century represents, today, both a coherent philosophical challenge to reductionist thinking in agriculture (see Lyons and Lawrence, 1999) and a practical alternative to those intensive farming methods - ones reliant upon the continued application of agri-chemicals and mechanical innovations - that emerged during the Scientific and Industrial Revolutions. It is now widely acknowledged that productivist (high tech) agricultural practices have led to an array of adverse ecological, health and social impacts throughout both the developed and developing world (Allen 1993; Redclift and Woodgate 1997). Despite the growing costs associated with these impacts, intensive agricultural practices have been rigorously promoted by both Australian and New Zealand governments since the late nineteenth century as an attempt to maintain and improve production efficiency (Barr and Cary 1992; Campbell 1996; Lawrence 1987; Tennant 1978). Additionally, chemicalintensive farming methods have been heralded by government and other research institutions as the key to economic prosperity of agricultural and rural communities. While there remain challenges in counteracting the environmental and other 'costs' associated with the adoption of, and continued reliance upon, European farming methods throughout Australia and New Zealand, there is little acceptance of the need fundamentally to abandon such practices. Continued acceptance and encouragement of these strategies has confirmed their pre-eminence and 'normalisation', while organic systems - often positioned in agri-food discourse as the antithesis of conventional agriculture - have been ridiculed and discredited, and consequently constrained from expanding. As an outcome of these constraints, the initial genesis of the organic agriculture industry throughout the 1920s and 1940s has been located at the periphery of broader changes occurring within agriculture. Concomitantly, and in an 'oppositional' sense, membership within the organic movement has represented the rejection of dominant conventional approaches to agriculture. It has, instead, embraced those practices involving acceptance of experimentation and 'local knowledge' which reside on the 'margins' of acceptability, and has grown in spite of, rather than because of, state actions in supporting agriculture (Belasco 1993; James 1993).

The genesis of the organic agriculture movement (and other low input systems) throughout this century has been driven initially by some concerned producers, and later health-conscious consumers. Points of departure from conventional agriculture have been in relation to the impacts of chemical-intensive practices upon the soil, as well as the questioning of the nutritional benefits of industrial food production (Ritchie and Campbell 1996). As a consequence of the culmination of these driving forces, alternative food distribution networks - many with prospects for long-term viability - were established throughout Australia and New Zealand (and indeed worldwide - see Lyons forthcoming a) by the 1980s. While this growth-initiated expansion resulted in a wider variety of organic produce being available in the marketplace, organic agriculture and 
food production still remained peripheral to dominant systems of food provision (Monk 1998; 1999).

Although remaining marginal in terms of contribution to the proportion of total agricultural production, organic food production systems have - especially during the last two decades - been significantly transformed. Without suggesting notions of 'convergence', they have come to resemble their conventional counterparts in many ways. This transformation has largely occurred as actors previously involved in conventional food production have found new and innovative ways to enter the organic food system referred to here as institutionalisation. For example, the organic industry has undergone significant change as an outcome of the entry of corporate capital at various sites in the organic food system (Buck et al. 1997; Burch et al. 1999; Guthman 1998; Lyons, 1999). In New Zealand, Heinz Wattie Ltd, McCains and Only Organic have contracted growers to supply organic inputs for the processing of frozen vegetables and baby foods while, in Australia, various companies including Uncle Tobys (up until 1997), Berrivale and Sandhurst have undertaken similar activities to produce a range of breakfast cereals and fruit beverages. Supermarkets, worldwide, have also begun to stock increasing quantities of organic food lines (Burch et al. 1999, Lockie, et al. forthcoming; Michelsen 1996). The recent entry of these actors has occurred alongside the formulation of national and international standards for organic produce. Guthman (1998), for example, argues that it is the codification of the organic industry through regulation and certification that has attracted corporate interest and has resulted in the 'dramatic' increase in organic production and consumption. Others (Burch et al. 1999; Campbell and Coombes 1999b) have pointed to green consumerism (which incorporates food security issues) as at least partly responsible for market growth within the organic industry segment.

This 'codification' of the organic industry in Australia and New Zealand occurred throughout the early 1980s, resulting in the formation of organic certification bodies. These bodies attempted to regulate producers, processors and retailers involved in this expanding industry. To date, seven nationally-recognised organic certification bodies exist in Australia, alongside a number of other, less formal, groups. These recognised bodies include; the Bio-Dynamic Research Institute of Australia, the Biological Farmers of Australia, the National Association for Sustainable Agriculture, Organic Food Chain, Organic Herb Growers of Australia, Organic Vignerons of Australia, and Tasmanian Organic-Dynamic Producers (Lovisolo 1997). Across the Tasman Sea, Bio Gro New Zealand, and the Biodynamic Farming and Gardening Association, are the two leading certifiers for organic and biodynamic produce.

Commencing in the early 1990s - and paralleling the 'self regulation' approach described above - both the Australian and New Zealand governments sought to play a more active role in the regulation of this industry. This occurred in response to growing recognition of the potential revenues that might be obtained from organic exports. As an outcome, in 1990 the Australian Government - under the auspices of the Australian Quarantine Inspection Service (AQIS) - established the Organic Produce Export Committee (OPEC) to administer a national export standard for organic produce (Lyon 1994; Lovisolo 1997). The purpose of OPEC is to approve an export-accreditation system for organic produce, with the aim of enhancing the export trade in organic products (Lovisolo 1997). As part of this mission, OPEC provides and oversees an internationally-recognised and 
government-approved set of standards for organic produce which are equivalent to the guidelines stipulated in Codex and EU Regulation (Lovisolo 1994;1997). OPEC has also established accreditation procedures for the production, labelling, processing, and handling of organic produce (Clarke 1991). Government support in the form of a national standard is based, more or less exclusively, on the intention to expand export earnings. That organics might be the vehicle appears to be of much less importance. The establishment of this regulatory structure does, nevertheless, represent an historical break from the pattern of government ridicule of organics. It also provides at least partial acknowledgment of organics as a 'legitimate' farming system within the context of capitalist agriculture.

A similar pattern of 'codification' has also occurred in New Zealand, where the government has involved industry in plans to expand organic export markets. State interest became evident in 1995 with the establishment of the Organic Products Exporters Group (OPEG), which aims to facilitate trade of New Zealand's organic produce. OPEG is a joint action group (JAG) established by the New Zealand Trade Development Board (Tradenz) to provide services to producers, retailers and distributors in order to increase exports of organic produce. The OPEG is comprised of a network of businesses, scientific institutions, government agencies and two independent organic certifying bodies. Many people involved in the New Zealand organic industry suggest the increased involvement by large companies, including Heinz Wattie and Zespri International, was the catalyst for government support - with government accepting that an 'organic' flavour might be a key to the generation of increasing levels of export revenue. Although OPEG was established to expand exports of organic produce, there has been little other government support for the industry's expansion. In particular, the New Zealand Ministry of Agriculture and Fisheries (MAF) has remained distant from growers and their concerns since the neo-liberalist restructuring of the New Zealand economy in 1984. As a consequence - and in stark contrast to what is occurring in Europe - MAF has played only a small, indirect, role in the expansion of organic farming systems. Although many within the organic movement would like to see MAF establish a national organic standard (similar to that administered by AQIS in Australia), until very recently MAF has shown no interest in this idea (see Fairweather 1999).

The recent changes which have occurred within the Australian and New Zealand organic industries highlight the various strategies employed by both corporate interests and the state in an attempt to expand export earnings from organic products. These changes have, in turn, led to a significant shift from the historical genesis of the organic movement. The changes highlight the increasing integration of actors previously unassociated with organics, and the subsequent 'resistance' to such integration by many of those wedded to what we have termed 'orthodox' systems of organic food provision. It is presently no longer accurate to conceptualise all organic food production as marginal to the broader changes occurring throughout agriculture and food production. Indeed, these changes represent the repositioning of organics as a formalised industry, that is one in which a 'modern' form of organics is becoming institutionalised alongside both high tech agriculture, and older - more orthodox - forms of organic production. The irony here should not be lost. What we appear to be witnessing is the entry of a cohort of growers who would have been once hesitant to undertake organic practices, but who, in economic rationalist terms, see market advantage in moving to something which can be conceived 
as 'organic agriculture'. While, many of these producers also share similar concerns with their 'orthodox' counterparts, they have been largely driven by economic imperatives. Many of the original - and once 'radical' and marginalised - organic producers have expressed concern with the entry of these growers. They have resisted incorporation into what they believe is a corrupted and/or inferior system of modern organic production. Despite their approach to agriculture now receiving general state endorsement, and being driven by the enthusiasm of elements of the corporate agri-food sector, this cohort of producers opposes the 'new' organics as much as it does high tech agriculture!

\section{Corporate Connections - Towards a New Organic Industry}

These recent processes of institutionalisation - characterised by agribusiness involvement and increasing state and industry regulation - have led to significant changes within the organic industry. Such changes are reflected most starkly by the increasing diversity of growers undertaking organic production. As described above, many 'new' growers have been encouraged to enter the industry in both Australia and New Zealand as a direct outcome of corporate involvement in the organic industry. For many, the sourcing of organic inputs by the food companies ensure growers a reliable market - as well as premium prices. In order to gain an understanding of the diversity of growers involved in the organic industry throughout each of these locations, in-depth face to face interviews were undertaken with 72 women and men organic farmers - 31 located in Australia and 41 in New Zealand. Farmers included in this study were accessed via lists supplied by two certification organisations in Australia (BFA and NASAA), and by Bio Gro in New Zealand. In order to expand the diversity of growers included in this study, growers were also accessed from the WWOOF1 list, and a snowball sampling technique was also utilised to enlist growers who might otherwise have been excluded from the study. Throughout these interviews, participants were asked a number of questions related to their decision to undertake organic methods, the markets for their produce, attitudes towards certification, government and corporate involvement in the industry, gender relations within the farm household and general concerns they believed the industry faced. Interviews were semi-structured, and there was scope throughout interviews for participants to raise issues not included within the interview schedule2. Prior to examining the responses of growers generated throughout these interviews however, it is important to account for the recent shift many food corporations in Australia and New Zealand (and indeed worldwide) have made towards sourcing and processing organic food lines.

Throughout both Australia and New Zealand the shift towards corporate involvement in organic agriculture has been understood in competing ways. It has been posited exportdependent food corporations have begun to alter their production practices as an outcome

1 WWOOFers are Willing Workers on Organic Farms. The WWOOF guide contains a list of organic farms that are willing to be involved in a cultural exchange by offering WWOOFers an opportunity to work on their fam in exchange for food and accommodation. WWOOF lists are available for both Australia and New Zealand.

2 These interviews are part of the fieldwork undertaken by Kristen Lyons from her forthcoming dissertation, "Situated Knowledges, Science and Gender: A Sociology of Organic Agriculture in Australia and New Zealand”. 
of the imposition of green protectionist trade barriers (Campbell and Coombes 1999a). In particular, companies such as Zespri International (kiwifruit) and Heinz Wattie (frozen vegetables), have shifted towards organic production in an attempt to increase access to growing international markets for so-called 'clean and green' foods (see Campbell et al. 1997). This was reiterated via interviews with representatives from Heinz Wattie, who suggested that the market for organic produce in countries such as Japan, the US and parts of Europe was unmet and was growing. In the Australian context, Lyons (1999) found that Uncle Tobys involvement in the production of an organic breakfast cereal reflected a marketing strategy to 'green' their corporate image, and thus appeal to the growing band of green consumers (Burch et al. 1999). Interestingly, the limited success of this marketing strategy - alongside increasing costs of production - resulted in the temporary removal of this product line. The product re-entered the market two years later following increased consumer concerns in relation to food - and spurred on particularly by the genetic engineering debate (see Lyons, forthcoming).

Another suggestion is that corporate involvement in the organic industry reflects a partial shift towards 'corporate greening'. The notion here is that firms are beginning to alter production methods, advertising and marketing strategies, and other procedures and practices so as to reduce the level of pollution and/or environmental impact and damage associated with the production and/or sale of their products (see Burch et al. 1999).

The recent entry of corporate capital into the organic industry, in concert with the tightening regulations imposed by current regulating bodies, has fostered new entrants supplying organic foods. Most of these growers have been farming conventionally for many years, and have recently made the shift to organic farming methods. Interviews undertaken with these growers revealed that this shift to organics represents a strategy to expand market access, as well as an opportunity to receive the premium paid on organic products. This is illustrated in the quotes below, which are drawn from interviews with producers from both Australia and New Zealand who currently supply food-processing firms with raw organic inputs:

Watties were really the catalyst. No one else jumped up and said they want organic products to process and sell. Watties made us aware of the market and made us put up our hands. . . It would be fair to say if Watties hadn't been on the scene we wouldn't be doing it. Because we wouldn't have recognised the market (Brendan, vegetable grower in Canterbury, New Zealand).

Oh, it was economic, my whole thing stems from an economic situation. . . Knowing that you're producing something that's reasonably clean and pollutionfree is important to me. But being able to produce it from a financial point of view is good. And if it wasn’t financially viable I wouldn’t do it (Michael, vegetable grower in Canterbury, New Zealand).

I'm probably more philosophically inclined that way which is probably why I thought about it in the first place, but the bottom line was the dollars coming in which is what you've got to do. If it's not economic we can't do it. It all boils down to 'are we going to make money out of it?', and if we can't, then we can't 
operate as a business, so you've got to be reasonably economic about it (Melissa, pea and lamb producer in Canterbury, New Zealand).

These quotes illustrate the significance of food-processing companies in attracting many 'new' growers to undertake organic practices, due to the premiums they offer organic producers. While some of these growers also indicate concern for broader social, health, and environmental issues, economic incentives have been the primary motive for the adoption of organic practices. Importantly, growers motivated by these economic issues are concentrated within particular locations in close proximity to processing factories. This is particularly evident in New Zealand, where Heinz Wattie and Zespri International have had success in encouraging growers (although not as many as they would have hoped!) to convert to organic practices (Campbell 1996; Campbell and Coombes 1999b; Campbell et al. 1997; Coombes and Campbell, 1998). In Australia however, food processing companies have not entered the organic food system to this degree, and the concentration of 'new' organic growers around particular locations is yet to occur.

The companies that have recently entered the organic food system have developed a number of strategies to ensure continued provision from growers. In 1990, for example, Heinz Wattie devised a 'Grow Organic With Watties' program, to encourage producers to convert to organic practices, and so recruit a new group of producers to supply organic products for an international market. In addition, Heinz Wattie provided direct support to organic growers, including visits by field officers, the distribution of newsletters and the regular funding of field days. The company was eager both to address any problems related to organic production, and to provide new information to the growers. As a consequence, the food processing companies such as Heinz Wattie have been able to insert themselves in many stages in the organic food system. This has generated an increased interest by producers in organic production, but has also increased control by the agri-food corporations over the entire (organic and non-organic) food production system.

An outcome of this involvement by the food processors - which has occurred alongside the evolution of national and international regulatory standards - is that the organic food industry has come to resemble conventional food systems. The shifts occurring throughout the organic industry stand in contrast to many of the interests held by longterm (orthodox) organic growers. Importantly, the expanding 'corporate' organic industry - characterised by food processing, packaging and international trade - stands in stark contrast to its foundation as a grassroots movement involving the sale of wholefoods through localised and informal markets (Belasco 1993). Consequently, there appears to be a growing bifurcation between the older 'orthodox' organic growers and the 'new' entrants to the organic industry.

\section{Resisting Incorporation - The Orthodox Organic Producers}

This rift between the 'new' and 'orthodox' growers is highlighted in an assessment of the motivations for 'going organic'. While these 'new' growers indicate the premiums paid for organic produce has led them to undertake organic practices (as discussed above), 
there are a large number of growers who present a range of other issues which have lead them to practice organic methods. It is important to note that while the majority of 'new' growers also raised some of these issues, without price premiums these concerns were not enough to encourage conversion to organic production. Conversely, for many 'orthodox' growers, premiums are irrelevant to their decision to 'go organic'. In particular, many growers emphasise that their concerns about health affects of agrichemicals resulted in the decision to produce organically:

... We had one episode where we had guys spraying aquatic weed . . . they had respirators and stuff like that which they were supposed to be in, but didn't wear them. And ah, it was a hot day so they stripped down to their singlets and what have you. When they came back, they had got the job done, then ah, they were all starting to feel sick. They were nauseous. They had nose bleeds. Um, in the end their fingernails, their nails came out, as a result of it. All the symptoms of poisoning by paraquat diquat (Russ, pea producer in Canterbury, New Zealand).

They were spraying the air all the time. And they had 80 percent of the kids in that area with respiratory problems. A huge percentage of primary children. Now it could have been manifest as asthma, or hay fever, or dizzy spells, or headaches, or that type of thing. Really really bad (Rachel, beef producer in Clifton, Queensland).

Alongside the concerns of these growers, many also revealed their suspicion that the environmental impacts of conventional methods of food production had yet to be fully realised - something that promoted the adoption of organic practices. For many of these growers, organic agriculture represents an environmentally-responsible farming option:

We are also interested in healing the earth. And Steiner was very much on about that, that's what we find Steiner is telling us, that we are ruining the earth, with chemicals and that sort of thing. And that is how we are ending up with deserts increasing and so on. And so the earth can heal, we need to use Biodynamic methods (Marchello, mixed vegetable growers in Motueka, New Zealand).

Oh, the reason why I am organic is probably because in my youth, sort of 15 to 18 you know, you could say there was a green wave that swept Europe, which started with the oil crisis and all the environmental catastrophes. And so, just the desire of German people to have a cleaner healthier environment, that sort of brought me into it (Frank, mixed vegetable and kiwifruit producer in Nelson, New Zealand).

It made sense to us. Living in Sydney and just being surrounded by buildings, we thought there must be more. I guess for me I was interested in organics over conventional because while living in Sydney I had become quite interested in environmental issues, not on a..., you know, not as in waving placards. I'm not that sort of person. But I am very interested in all that sort of stuff (Jane, orchardist in Takaka, New Zealand).

In addition, many growers also suggest lifestyle appeals were an important stimulus to experimentation with, and adoption of, organic farming: 
I prefer to live in the country. And we saw the opportunity here to start from scratch virtually. We don't have the same ideals as non-organic farmers (Kate, vegetable grower in Yeppoon, Queensland).

For me I would say it was the lifestyle that attracted me ... Well you don't get much pay, but it's about much more than money, we work for ourselves. Oh it's satisfying, and much more interesting too. If you get bored with one thing you can go onto another (Daphne, mixed vegetable grower in Motueka, New Zealand).

My husband was an engineer, and he wanted to change his job. He wanted to do something different. He wanted to farm . . . and I wanted to be somewhere that is good for my children to live and grow up, without chemicals... You get a lot of fresh air, there are a lot of advantages, it is a quiet life (Naomi, vegetable grower in Childers, Queensland).

It just seemed an obvious thing to do. I think if you move to acreage and you're looking at being self-sufficient, which was the initial plan, then I think you know, some sort of natural method of farming has to be the way to go. There doesn't seem much point in going and living on acreage and pouring chemicals into the stuff (Mark, orchardist in Murwillumbah, New South Wales).

We love it here, and you know, I'm older, I'm 48 now, and I've got to look at what I like doing and the way I want to spend the rest of my life. I just enjoy farming (Rick, vegetable grower in Yeppoon, Queensland).

Many producers expressed more than one of the above concerns in explaining their own involvement in the organic industry - they are not mutually exclusive, and indeed, many growers believe health, environment and lifestyle are integrally linked. For many of these growers, the recent entry of corporate organic growers - motivated primarily by economic incentives - poses a significant threat to the future viability of the industry. Many growers in New Zealand indicate the entry of these new actors may threaten the integrity of the industry, by altering definitions of 'organic' and what might be considered 'acceptable' organic practices. For example, these growers suggest large food processing companies have influenced national and international organic standards to reflect their own interests, and in turn, have undermined the organic industry. Growers suggested processing companies have been able to bend rules to make accessing raw inputs easier, and that some of these changes have been incompatible with the broader objectives of the organic movement. That growers in New Zealand raise this to an extent not realised in Australia reflects the significance of food processing firms - such as Heinz Wattie - throughout the last decade in shaping the New Zealand organic industry.

Reflecting opposition to the arrival of these 'new' organic growers and corporate interests, orthodox organic growers have employed a number of strategies to contest these changes. These strategies represent significant challenges to processes of institutionalisation, and suggest that the 'organic industry' - rather than being a single entity - should to be considered in the plural form. 
Creation of Stricter Guidlines

Sites of resistance are present in both Australia and New Zealand. In both nations small numbers of organic growers have recently devised their own organic certification systems to regulate organic production, and provide quality-assured organic produce to consumers. This has occurred throughout the 'Top of the South' in New Zealand, and in Australia's north-east New South Wales. Importantly, growers in these regions emphasise - as suggested in the earlier quotes - lifestyle, health and the environment in their decision to produce organically. The establishment of local and informal organic certification systems by growers in these regions marks a historic point for the organic industry, as it stands in direct opposition to the growing formalisation and institutionalisation of the organic industry by the government/industry sectors. Many producers indicate their involvement in these alternative regulatory systems reflects their opposition to the rising costs of certification, and for a few growers it signifies their distrust of external auditing bodies. In the past these farmer-based certification systems in both Australia and New Zealand have enabled growers to ensure product quality to consumers. While organic growers certified by these programs have been unable to sell their products on the international market (where they require internationally-recognised certification), these certification systems have been successful in generating sales on the local market. Such certification systems represent the antithesis to nationally recognised formal regulatory bodies, as they are not independently audited, and therefore limit growers from accessing domestic and international markets. All 'new' organic growers emphasise the importance of meeting internationally-recognised certification standards, and many seek to distance themselves from 'breakaway' or 'fringe' groups, such as those devising their own standards. For 'new' growers, strategies such as these undertaken by long term 'orthodox' growers are perceived as unprofessional, and detrimental to the image of the organic industry.

\section{Reinforcing Networks Outside the Companies}

In addition to this resistance, many growers have also established informal networks for the generation and exchange of knowledge. While conventional farmers have historically utilised information deriving from scientific advisory bodies and agricultural consultants, many organic growers ignore - and often directly challenge - such knowledge bases.

Throughout both Australia and New Zealand, groups of growers have organised and have met regularly to exchange information with other growers. Much of this shared information is generated by growers themselves through trial and error, as well as through growers own research and reading, rather than the information sources available to conventional rural producers (see Lyons 1998). It is interesting to note that the majority of 'new' growers in New Zealand also engage in discussion groups with other growers, however these are organised and facilitated by processing companies. As indicated earlier, Heinz Wattie supplies much support to growers in the form of information sheets, field days and agricultural consultants. While these field days bear some resemblance to the discussion groups other organic growers participate in, they tend to draw from the expert advice of agricultural consultants and scientific advisory services. In contrast, many organic growers indicated that their participation in discussion groups reflected their opposition to scientific advisory services, of which they were distrustful.

Ignoring Corporate Price Signals and Other Enticements 
The orthodox growers have often entered organics for reasons of personal health, environmental integrity, and closer community participation. Maximising profits is not seen as the main ingredient to a better lifestyle. In many cases their market is small and unreliable, but they resist the 'price signals' of the corporations which are seeking their involvement. This represents a rejection not only of corporate monetary enticements to grow for a wider marketplace, but also of the wider activities of firms seeking profit from organics. Many view the entry of the corporations with suspicion - believing that the policies of such groups is antithetical to an holistic, community based, approach to farming.

\section{Discussion: Association or Polarisation?}

That there has been a recent entry into farming of organic producers who are very different from the core group of 'orthodox' organic growers should not necessarily be an immediate concern for consumers or producers. Are not the correct market signals finally beginning to flow through to conventional (high tech) farmers? If this latter group begins to use less chemicals and/or produces in a more sustainable manner, should not this be viewed as a highly desirable outcome? If we are also witnessing some form of corporate greening - as food corporations and supermarkets strive to deliver more wholesome, clean and green, organic, foods to appreciative consumers - is this not also a benefit for the farmers, for consumers and for the environment? Indeed, although there might be resistance might this not be best construed as a reactionary response from a group of ideologically-motivated growers jealous that they might be being beaten at their own (organic marketing) game by a more entrepreneurial cohort of producers? Finally, as Fairweather (1999) has argued, in New Zealand there are many conventional farmers who have never fully embraced high input agriculture. It might be relatively easy for such producers to adopt organic farming methods. Given the premiums on offer and the likelihood of advantageous environmental outcomes, why shouldn't they be encouraged by government agencies to do so?

In order to understand why suspicion and resistance might be accompanying the growth in the new organics it is useful to consider recent developments in the US. In 1997 the United States Department of Agriculture (USDA) sought to develop and apply a set of legally-binding standards for organically-produced foods. The rules sought to set a standard for 'organic' well below that proposed by the organic growers' National Organic Standards Board. Under the proposed rules the USDA would not only have monopoly rights over the term 'organic', but also would have redefined the meaning of the term. It would allow for the use of food irradiation technology, the recycling onto agricultural lands of toxic sludge, the use of genetically-engineered organisms, and would condone the current practices - offensive to most orthodox organic growers - of the intensive confinement of birds and animals (see Lilliston and Cummins 1998).

The aim of the USDA legislation was not, according to Lilliston and Cummins (1998: 196), to stimulate a new group of producers to adopt the rigorous standards imposed by existing regulating bodies in the organics industry, but to reduce to the lowest common denominator what constituted 'organic'. The latter would have the effect of promoting the 
continuation of a productivist agriculture, while allowing producers and corporations to take advantage of 20 percent annual growth in the organics market in the US. It would ensure that many of the environmentally-damaging synthetic inputs supplied by agribusiness - together with the profits of those companies - would not be threatened as the organic industry expanded. Proposed ownership of the term organic by the USDA would allow government agencies to protect the interests of the large farmers and corporations while undermining those of the orthodox organic producers - those who had spent so much time and energy legitimising the term in the eyes of the public. The Clinton Administration's attempts to redefine organic agriculture resulted in considerable opposition - although not sufficient, it would seem, to prevent a modified version of the legislation from being passed, later this year, by government (Lilliston and Cummins 1998: 200).

There is sufficient cynicism within the 'orthodox' organic industry in Australia and New Zealand to allow a prediction that any future 'incorporation' will strengthen the hand of high tech farming (and of the corporations which serve it) as pressure is placed upon governments to water down the strict guidelines imposed by the industry's current regulating bodies. Growers were suspicious of the 'green' credentials of those profiting from the new organics. But, as Lyons (1998) has reported many of the new, corporatelinked, organic growers also sought to distinguish themselves from the orthodox growers. They were

not influenced by an interest in the environment, but were purely motivated to undertake organic farming for economic returns, and sought to differentiate themselves from environmentalists or 'greenies' (Lyons 1998: 61).

Here, then, is evidence of what might be a growing, and irreconcilable, division among the organic producers based on particular conceptions of the 'meaning' of organic and its place in a more sustainable agriculture. The more that organics become a corporatecommercial reality, the less orthodox producers might be expected to accept the new parameters of production. What does it tell us, for example, if 'organic' production methods are employed on the farm, but those products are grown in a monocultural system with high water demands and which encourages the proliferation of pests and diseases? What if the organic products which leave the farm are then processed, transported long distances from the sites of production, and presented to consumers in styrofoam or other environmentally-polluting packaging? The orthodox organic growers would have good reason to be concerned that a corporate-linked organics has been 'used' to trick consumers into believing that they are receiving 'clean and green' foods, when the downstream system remains largely untouched, and the use of energy and production of wastes is no different from that of any other commodity within industrial agriculture (Burch et al. 1999). Yet, as appears to be the case if companies, such as UK's Sainsbury, have accepted that they must move back into the chain of production and distribution to ensure that fruit and vegetable products are grown in ways that minimise soil loss, reduce chemical use, and are transported in ways which minimise the use of fossil fuels (see Burch et al. 1999) surely this represents a positive outcome for consumers and the environment? 
If it can be accepted, as suggested in the introduction, that there is an identifiable 'greening' of western society, it is important to assess the ability of systems of agricultural production and distribution to meet the needs/demands of consumers for clean and green foods, and to contribute to sustainable modes of production. What we have identified in this analysis is the bifurcation of the organics movement as it responds to consumer demands. Orthodox organic producers believe that their 'rigorous' and 'unbiased' systems of regulation - combined with a philosophical predisposition toward small scale, 'community', and anti-corporate forms of production and distribution - are the best ways to achieve these ends. In contrast, the new organic producers are drawn to the industry for its profit-making potential - an entirely legitimate motivation within a system of capitalist production and exchange.

This tension may be resolved through the marketplace. In Australia and New Zealand, the 'new' organic producers now have ready access to distribution outlets, while the orthodox producers continue to produce for small (usually regional) domestic markets. Are we viewing a very significant division of the organic industry into those who will have access - via the intervention of the corporate food production sector - to global markets alongside those who are only able to sell to smaller (in growth and profit terms), domestic markets? If this is indeed how the division is best understood, one might predict the following:

- the corporate-linked organic sector will expand in line with the demands of overseas consumers for 'green' foods

- $\quad$ pressures will be exerted to weaken the rules of regulatory bodies so as to accommodate elements of a 'high tech' approach to organic agriculture

- the domestic-based organic sector will continue to grow, but will have an 'untidy' form - representing a combination of orthodox growers and corporatelinked growers - who are seeking the organic label to sell produce in bulk to whatever markets they can capture

- $\quad$ there will be increasing polarisation between 'orthodox' organic producers and the new, more market-oriented, producers which may manifest itself in the acceptance by the latter of increasingly lax organic standards

- the hope that many had of organic production resulting in more sustainable farming systems will be largely destroyed: 'organic' will be a name without much susbstance.

Whether or not the potential reduction of standards might lead to a rejection by domestic or international consumers is, of course, open to some debate.

In terms of the theme of this book, modern organics would not seem to herald a return to an 'old rurality'. While the orthodox organic producers could be considered close to this largely non-market form of production, and are likely to continue to produce for smallscale and domestic markets, those with capital - the corporate-linked and capital intensive producers - are on a different trajectory. They can remain rural in late modernity by accepting two otherwise contradictory ideas: the sanctity of the market, yet the need to reject productionist agriculture to fulfill the demands of that market. 


\section{Conclusion}

Organic agriculture is occupying a new space in agri-food discourse, and practice, in Australia and New Zealand. 'Organic' is no longer a term that can be applied in a perjorative way to those 'alternative' producers who choose to reject high tech agriculture in the production of foods and fibres. Driven by commercial realities relating to wider tendencies of 'greening' a new group of producers has emerged who happily accept the 'organic' label. What they have done, however, is to align their interests with an agri-food sector bent upon capturing markets through the sale of organically-produced farm commodities. Those orthodox organic producers who, in previous decades, have fought for the wider acceptance of organic production, and have developed regulations to ensure the 'purity' of organics, are currently having their own approach to farming challenged by corporate firms and governments eager to re-define the meaning of organics. This is related to the imperative within existing farming systems of generating new commercial opportunities.

The orthodox growers have not only been cynical of any premature celebration of the wider acceptance of an organic ethos, but have also sought ways to resist 'incorporation'. Such actions have included: creation of even stricter guidelines - in the face of moves by corporations and government to 'redefine' (downgrade) the meaning of organics; reinforcement of their own, community-based, networks as sources of information and interaction; and rejection of the 'price signals' from companies which desire their involvement in the production of inputs to the corporate food industry.

Whether such resistance represents a long-term, successful, strategy to avoid contact with the corporate sector; whether rejection of the corporate sector is likely to dissipate; whether the temptation to produce organically - under the direction of the corporate firms and for high profits - will be accepted by the 'orthodox' organicists; whether the bulk of those resisting 'incorporation' will emerge from corporate interventions with their own regulatory system and markets intact; whether any 'corporate organics' can provide a sustainable basis for food production and distribution; and whether the state will act on behalf of orthodox growers, or the new growers and the agri-food industry, are questions which cannot be answered at this time. What can be said is that the organic industry in Australia and New Zealand is in a period of flux with internal divisions providing an intriguing focus for an assessment of the potential for the older 'high tech' approach to agriculture to be modified for social and environmental good.

\section{References}

Allen, P. (ed.)(1993) Food for the Future: Conditions and Contradictions of Sustainability, John Wiley: New York.

Avery, D. (1995) Saving the Planet with Pesticides and Plastic: the Environmental Triumph of High-Yielding Farming, Hudson Institute: Indianapolis.

Barr, N. and Cary, J. (1992). Greening A Brown Land. The Australian Search for Sustainable Land Use, Macmillan: Melbourne.

Belasco, W. (1993). Appetite for Change, Cornell University Press: Ithaca. 
Buck, D. Getz, C. and Guthman, J. (1997). "From farm to table: the organic vegetable commodity chain of northern California." Sociologia Ruralis 37, 1 :3-19.

Burch, D. Lyons, K. and Lawrence, G. (1999). "What do we mean by 'green'? consumers, agriculture and the food industry", Consuming Foods, Sustaining Environments, Proceedings from the $6^{\text {th }}$ Annual Agri-food Research Network, Central Queensland University: Rockhampton.

Buttel, F. (1993) Environmentalization and Greening: Origins, Processes and Implications, in Harper, S. (ed.) The Greening of Rural Policy: International Perspectives, Belhaven: London.

Campbell, H. (1996). Recent Developments in Organic Food Production in New Zealand: Organic Food Exporting in Canterbury, Department of Anthropology: Dunedin.

Campbell, H. and Coombes, B. (1999a). "Green Protectionism and Organic Food Exporting from New Zealand: Crisis Experiments in the Breakdown of Fordist Trade and Agricultural Policies", Rural Sociology 64, 2: 302-319.

Campbell, H. and Coombes, B. (1999b). "New Zealand's organic food exports: current interpretations and new directions in research", Pp. 61-74 in D. Burch, J. Goss and G. Lawrence (eds) Restructuring Global and Regional Agricultures: Transformations in Australasian Agri-food Economies and Spaces, Ashgate: Aldershot.

Campbell, H. Fairweather, J. and Steven, D. (1997) Recent Developments in Organic Food Production in New Zealand: Part 2, Kiwifruit in the Bay of Plenty. Department of Anthropology: Dunedin.

Clarke, R (1991). "Organic foods: for better or worse". Food Australia, 43, 1: 12-14.

Coombes, B. and Campbell, H. (1998) Recent Developments in Organic Food Production in New Zealand: Part 4: The Expansion of Organic Food Production in Nelson and Golden Bay, Department of Anthropology: Dunedin.

Eder, K. (1996). The Social Construction of Nature: a Sociology of Ecological Enlightenment, Sage: London.

Fairweather, J. (1999) "Understanding how farmers choose between organic and conventional production: results from New Zealand and policy implications", Agriculture and Human Values 16: 51-63.

Guthman, J. (1998) "Regulating meaning, appropriating nature: the codification of California organic agriculture”, Antipode 30, 2: 135-154.

Harper, S. (ed.)(1993) The Greening of Rural Policy: International Perspectives, Belhaven: London.

Hassall and Associates (1990) The Market for Australian Produced Organic Food, RIRDC: Canberra.

James, A. (1993). "Eating green(s) discourses of organic food" Pp. 205-218, in K. Milton (ed.) Environmentalism. A View From Anthropology, Routledge: London.

Kinnear, S. (1999) Overview of the Organic Industry in Australia, Presented at Farming for the Future. Organic Produce for the $21^{\text {st }}$ Century. Mackay, Queensland, 2223 September.

Lawrence, G. (1987) Capitalism and the Countryside: the Rural Crisis in Australia, Pluto Press: Sydney.

Lawrence, G. (1996) "Contemporary Agri-food Restructuring: Australia and New Zealand" Pp. 45-72 in D. Burch, R. Rickson and G. Lawrence (eds) 
Globalization and Agri-food Restructuring: Perspectives from the Australasia Region, Avebury: Aldershot.

Lawrence, G. (1999) "Agri-food Restructuring: A Synthesis of Recent Australian Research", Rural Sociology 64, 2: 186-203.

Lawrence, G., Lockie, S. and Lyons, K. (1999) "'Healthy for you, healthy for the environment': corporate capital, farming practice and the construction of 'green' foods" Rural Society. 9, 3: 543-554.

Lilliston, B. and Cummins, R. (1998) "Organic vs 'organic': the corruption of a label", The Ecologist 28, 4, July/August: 195-200.

Lockie, S. (1999) "The state, rural environments, and globalisation: 'action at a distance' via the Australian Landcare program", Environment and Planning A, 31: 597611.

Lockie, S. Lyons, K. and Lawrence, G. (forthcoming) “Constructing 'Green’ Foods: Corporate Capital, Risk and Organic Farming in Australia and New Zealand”, in Agriculture and Human Values.

Lovisolo, R. (1994). "Harmonisation of Trade Aspects of Organic Produce", paper presented at The Tenth Scientific Conference of the International Federation of Organic Agriculture Movements, Lincoln University, New Zealand.

Lovisolo, R. (1997). "The Codex Alimentarius Commission - What it Means to Australia and the Labelling of Organic Food". Presented at Australian Institute of Agricultural Scientists and Technologists National Conference, Ulverstone, Tasmania.

Lyon, N. (1994) "Organic farming to attract new markets" Australian Farm Journal 4,10: 62-63.

Lyons, K. (1998) “Understanding organic farm practice: contributions from ecofeminism”, in D. Burch, G. Lawrence and J. Goss (eds) Australasian Food and Farming In A Globalised Economy: Recent Developments and Future Prospects, Monash Publications: Melbourne.

Lyons, K. (1999). "Corporate environmentalism and organic agriculture in Australia: case study Uncle Tobys", in Rural Sociology 64, 2: 251-265..

Lyons, K. (forthcoming a) "From Sandals to Suits: Green Consumers and the Institutionalisation of Organic Agriculture” Consuming Foods, Sustaining Environments, Proceedings from the $6^{\text {th }}$ Annual Meeting of the Agri-Food Research Network, CQU Press: Rockhampton.

Lyons, K. (forthcoming b) Situated Knowledges, Science and Gender: A Sociology of Organic Agriculture in Australia and New Zealand, PhD thesis, Central Queensland University” Rockhampton.

Lyons, K. and Lawrence, G. (1999) "Alternative knowledges, organic agriculture and the biotechnology debate", Culture and Agriculture. 21, 2: 1-12.

Malcolm, B., Sale, P. and Egan, A. (1996) Agriculture in Australia: an Introduction, Oxford: Melbourne.

Michelsen, J. 1996. "Organic farmers and conventional systems: the recent expansion of the organic food market in Denmark." American Journal of Alternative Agriculture 11, 1:18-23.

Monk, A. (1998) "The Australian organic basket and the global supermarket" Pp. 69-82 in D. Burch, G. Lawrence, R. Rickson, and J. Goss (eds) Australasian Food and Farming in Globalised Economy: Recent Developments and Future Prospects, Monash: Melbourne. 
Monk, A. (1999) "The Organic Manifesto: Organic Agriculture in the World Food System" Pp. 75-86 in D. Burch, J. Goss and G. Lawrence (eds) Restructuring Global and Regional Agricultures: Transformations in Australasian Agri-food Economies and Spaces, Ashgate: Aldershot.

Penfold, C. and Miyan, M. (1998) "Organic agriculture - now and the future" in D. Michalk and J. Pratley (eds) Agronomy - Growing a Greener Future, Pp. 669672 in Proceedings of the $9^{\text {th }}$ Australian Agronomy Conference, Australian Society of Agronomy: Wagga Wagga.

Ritchie, M. and Campbell, H. (1996) "Historical development of the organic agriculture movement in New Zealand" in H. Campbell, J. Fairweather, and D. Steven, Recent Developments in Organic Food Production in New Zealand, Department of Anthropology: Dunedin.

Redclift, M. and Woodgate, G. (1997) The International Handbook of Environmental Sociology, Edward Elgar: Cheltenham.

Rural Industries Research and Development Corporation. (1996) The Domestic Market for Australian Organic Produce. RIRDC Research Paper No 96/1. Canberra.

Sachs, W., Loske, R., and Linz, M. (1998) Greening the North: A Post-Industrial Blueprint for Ecology and Equity, Zed Books, London.

Saunders, C. Manhire, J. Campbell, H. and Fairweather, J. (1997) Organic Farming in New Zealand: An Evaluation of the Current and Future Prospects Including an Assessment of Research Needs. MAF Policy Technical Paper. Department of Economics and Marketing, Lincoln University: Canterbury.

Tennant, D. (1978). Soil Amending Technology, Grassland Farming and New Zealand Economic Development, (PhD thesis) Department of Geography, Massey University: Palmerston.

Thomashow, M. (1995) Ecological Identity: Becoming a Reflective Environmentalist, MIT Press: Massachusetts.

Youngberg, G. Schaller, N. and Merrigan, K. (1993) "The sustainable agricultural policy agenda in the United States: Politics and Prospects" Pp. 295-318, in P. Allen (ed.) Food for the Future: Conditions and Contradictions of Sustainability, John Wiley: New York 